\title{
The Potential of 9,10-Anthraquinone in Inhibiting Human Cancer Cells Growth
}

\author{
Irmanida Batubara ${ }^{1,2}$, Arif Rakhman Hakim ${ }^{3}$, Silmi Mariya ${ }^{4}$, Suminar Setiati Achmadi ${ }^{1,2}$, \\ Valentina Sokoastri ${ }^{3}$, Agustin Sri Mulyatni ${ }^{3}$, Rohayati Suprihatini ${ }^{3}$ \\ ${ }^{1}$ Tropical Biopharmaca Research Center, The Institute for Research and Community Service, IPB University, Bogor, Indonesia \\ ${ }^{2}$ Department of Chemistry, Faculty of Mathematics and Natural Sciences, IPB University, Bogor, Indonesia \\ ${ }^{3}$ PT Riset Perkebunan Nusantara, Bogor, Indonesia \\ ${ }^{4}$ Primate Research Center, IPB University, Bogor, Indonesia
}

\section{ARTICLE INFO}

Received : 03 September 2020

Reviewed : 29 September 2020

Accepted : 04 January 2021

\section{Keywords:}

anthraquinone, tea, human cancer cells, antiproliferation

\author{
*Corresponding author: \\ Irmanida Batubara \\ Department of Chemistry, Faculty \\ of Mathematics and Natural Sciences, \\ IPB University, Bogor, Indonesia \\ ime@apps.ipb.ac.id
}

\begin{abstract}
A BSTRACT
Background: 9,10-Anthraquinone (9,10-AQ) is a contaminant on some agricultural products and considered as carcinogenic based on EU Regulation No. 1146/2014. Except for little evidence on experimental rats, there is no strong proof regarding the carcinogenicity in humans. Therefore, it is essential to find a safe dose of this compound since the difference in 9,10-AQ levels will affect cancer cell growth. This research aims to find the 9,10-AQ concentration that does not proliferate the human cancer cells under in vitro study.
\end{abstract}

Methods: In determining the 9,10-AQ concentration that does not proliferate the cancer cells growth, 0.01 to $500 \mathrm{mg} / \mathrm{L} \mathrm{9,10-AQ} \mathrm{was} \mathrm{directly} \mathrm{tested} \mathrm{on} \mathrm{four} \mathrm{human} \mathrm{cancer} \mathrm{cells} \mathrm{(colorectal}$ carcinoma HCT 116, colon adenocarcinoma WiDr, breast cancer MCF-7, and cervical cancer HeLa), and the viability of the cells was counted via (3-[4,5-dimethylthiazol-2-yl]-2,5-diphenyl tetrazolium bromide) assay. In the gene expression level, the effects on a selected cancer cell line were determined by $\mathrm{qRT}$-PCR against $B A X, B C L-2, P C N A$, and $P 53$.

Results: The result indicates that 9,10-AQ up to $500 \mathrm{mg} / \mathrm{L}$ concentration does not proliferate the cell's growth but instead inhibits those four cancer cells' growths. The concentration of 9,10-AQ that inhibits $50 \%$ the cancer cells growth (IC50) value was $321.8 \mathrm{mg} / \mathrm{L}(1.55 \mathrm{mM})$ against HCT 116 and above $500 \mathrm{mg} / \mathrm{L}$ (above $2.40 \mathrm{mM}$ ) against WiDr, MCF-7, and HeLa. The 9,10-AQ at 500 $\mathrm{mg} / \mathrm{L}$ (or $2.40 \mathrm{mM}$ ) increases $B A X$ expression and acts as an apoptotic agent on HeLa cells.

Conclusions: The investigation has shown that 9,10-AQ up to $500 \mathrm{mg} / \mathrm{L}$ concentration does not proliferate the cancer cell growth; instead, it inhibits the HCT 116 and HeLa cells growth. We have preliminary evidence regarding the apoptotic mechanism of 9,10-AQ by increasing $B A X$ gene expression on HeLa cells.

\section{INTRODUCTION}

The 9,10-anthraquinone (9,10-AQ) is a compound formulated with insecticides and fungicides and acts as bird repellent [1]. Its presence in agricultural products, such as in fruit, vegetable, oil, spices, and animal product in European Union, is prohibited according to European Food Safety Authority (EFSA) [2]. Therefore, this synthetic compound is classified as Carc 1B based on some sufficient evidence for animal carcinogenicity $[3,4]$.

The maximum residue level (MRLs) of 9,10-AQ is currently set to be $0.01 \mathrm{mg} / \mathrm{kg}$, which applies to agricultural products such as fruit including pine fruit, citrus fruit, stone fruit, root and tuber, vegetable including bulb vegetable, fruiting vegetable, brassica vegetable, leaf vegetable, legume, stem vegetable, fungi, seaweed, cereal, sugar plant, and animal products. The MRL is slightly higher for tree nuts, oilseeds, oil fruit, tea, coffee, herbal infusion, cocoa, spices seed, rhizome, and bud, which is $0.02 \mathrm{mg} / \mathrm{kg}$. Nonetheless, the EFSA admits that due to the lack of toxicological data on 9,10-AQ, it is impossible to assess whether a standard $0.01 \mathrm{mg} / \mathrm{kg} \mathrm{MRL}$, as defined by Regulation (EC) No $396 / 2005$, would provide adequate consumer protection in the event of abuse [2]. The carcinogenicity of 9,10$A Q$ in humans has not been widely reported. The only reports on chronic neurotoxic symptoms due to 9,10-AQ in humans are visual impairment, acute oral poisoning, and skin irritation $[5,6]$. 
Cancer cell lines are typical for in vitro model systems to assay a compound's effect on cancer cell growth, such as determining whether the compound is proliferating the cell (has carcinogenic potency) or inhibit cell growth (has antiproliferation potency). One advantage of using cell culture is its consistency that can be obtained. It is known that the concentration difference applied to the cells will have a different effect. Thus, it is essential to determine the 9,10-AQ concentration that does not proliferate the cancer cell growth. This paper presents, for the first time, some experimental results of directly administering several doses of 9,10-AQ to the development of four types of human cancer cells, namely (1) human intestinal cancer cells HCT 116 (ATCC CCL 247), (2) WiDr human intestinal cancer cells (ATCC CCL 218), (3) MCF-7 human breast cancer cells (ATCC HTB 22), and (4) HeLa cervical cancer cells in humans (ATCC CCL 2). Through this experiment, the 9,10-AQ dose that caused cancer cells' proliferation, and the safe dose (same level as the control) will be disclosed. The mechanism of the 9,10-AQ through $B A X$, $B C L 2, P 53$, and PCNA expression on selected cancer cell lines will be discussed..

\section{METHODS}

\section{Evaluation of cytotoxicity based on tetrazolium dye (MTT) assay}

The 3-[4,5-dimethylthiazol-2-yl]-2,5-diphenyl tetrazolium bromide (MTT) assay was used to evaluate the cytotoxicity of the 9,10-AQ. The protocol relied on the yellow tetrazolium salt's cleavage, MTT, forming a soluble blue formazan product by mitochondrial enzymes. The quantity of formazan was proportional to the population of living cells present under MTT exposure [7]. The tested cancer cells were human colorectal carcinoma HCT 116 (ATCC CCL-247), human colon adenocarcinoma WiDr (ATCC CCL-218), human breast cancer MCF-7 (ATCC HTB-22), and human cervical cancer HeLa (ATCC CCL-2).

The cells were cultured in a medium containing Dulbecco's modified eagle medium (DMEM, Gibco USA), $10 \%$ fetal bovine serum (FBS, Gibco USA), and $1 \%$ antibiotic (Penicillin Streptomycin, Invitrogen USA) in a favorable environment $\left(37{ }^{\circ} \mathrm{C}, 5 \% \mathrm{CO} 2,90 \%\right.$ humidity) The cells were sub-cultured and seeded into a 96-well tissue culture plate with 5000 cells/well to adhere for 18-20 hours in a growth medium; each concentration was performed in triplicate. The following day, the medium was removed from the wells and replaced with 9,10-AQ (TCl India, CAS No. 84-65-1) in a growth medium. Dimethyl sulfoxide (DMSO) was added to facilitate the sparingly soluble 9,10-AQ's homogeneous solution, with the final concentration of DMSO $0.5 \%$ in each well. The plates were then incubated with 9,10-AQ in various concentrations: $500,250,150,25,2,0.02$, and $0.01 \mathrm{mg} / \mathrm{L}$ for 48 hours. Tetrazolium salt, MTT (Sigma USA), was added to each well in the plates (10 $\mu \mathrm{L}$ of $5 \mathrm{mg} / \mathrm{mL}$ in PBS). The plates were further incubated for 4 hours. The medium was then removed, and $1 \mathrm{~N}$ $\mathrm{HCl}$ in isopropanol (100 $\mu \mathrm{L})$ (Merck, USA) was added. Finally, the absorbance at $\lambda 562 \mathrm{~nm}$ of the plates were read using a microplate reader (BioRad USA). The absorbance values were blanked against $1 \mathrm{~N} \mathrm{HCl}$ in isopropanol, and absorbance of the cells exposed to the respective medium was taken as $100 \%$ cell viability (taken as negative control). The $50 \%$ inhibition concentration (IC50) of 9,10-AQ against each cell was determined based on the correlation between percent inhibitions and the concentrations. The concentration on the correlation that gives $50 \%$ inhibition is the IC50 value.

The HeLa cells were treated with 9,10-AQ at 250 $\mathrm{mg} / \mathrm{L}$ and $500 \mathrm{mg} / \mathrm{L}$; in this study, untreated cells were used as a control. The concentrations of 9,10-AQ used in this study for cell exposure were chosen from a previous MTT assay result. Treated cells and untreated cells were incubated for 48 hours at $37^{\circ} \mathrm{C}$ in $95 \%$ humidity and 5\% CO2 (Forma Series II Water-Jacketed CO2 Incubator, Thermo Fisher Scientific, Waltham, MA). According to the manufacturer, mRNA was extracted from cells using the RNeasy kit (Qiagen, Germany) and reversetranscribed using SuperScript ${ }^{\circledR}$ III Reverse Transcriptase (Invitrogen, USA) accordingly. We employed the quantitative real-time reverse transcriptase-polymerase chain reaction (qRT-PCR) in measuring the expression of markers for apoptosis marker (BAX, BCL2, P53), proliferation markers (PCNA); GAPDH was used as the internal calibrator gene. Table 1 displays the sequence of primers used. Reactions were performed using SsoFast ${ }^{\mathrm{TM}}$ EvaGreen ${ }^{\circledR}$ Supermix (Biorad, Hercules, Un) on the iCycler iQ5 (Biorad, USA). Relative gene expression followed the delta-delta threshold method (2- $\triangle \Delta C T$ ) with the CT gene target normalized with $C T$ reference (GAPDH gene) [8].

\section{Statistical Analysis}

Data are presented as average from triplicate data for $\%$ inhibition and gene expression. The \% inhibition and gene expression of treatment were compared with control cells using t-tests at $\alpha=.05$.

\section{RESULT}

The 9,10-AQ's effect is diverse in the growth of the cancer cell lines (Figure 1). Surprisingly, a high concentration of 9,10-AQ (25-500 mg/L) inhibits the cell growth for HCT 116 and HeLa cells, but cell growth inhibition for WiDr and MCF-7 cells are found at sufficiently high concentration (250 and $500 \mathrm{mg} / \mathrm{L}$ ). 
Table 1. Primers sequences

\begin{tabular}{|c|c|c|c|}
\hline \multirow[t]{2}{*}{ Marker } & \multicolumn{2}{|c|}{ Sequence $\left(5^{\prime}-3^{\prime}\right)$} & \multirow[t]{2}{*}{ References } \\
\hline & Forward & Reverse & \\
\hline$B A X$ & CCCGAGAGGTCTTTTTCCGAG & CCAGCCCATGATGGTTCTGAT & [9] \\
\hline$B C L 2$ & GCTCTAAAATCCATCCAG & ССТСТССАТСАТСААСТТ & [9] \\
\hline P53 & GAGCTGAATGAGGCCTTGGA & CTGAGTCAGGCC CTTCTGTCT T & {$[10]$} \\
\hline PCNA & GAAGCACCAAACCAGGAGAA & TATCGGCATATACGTGCAAA & {$[11]$} \\
\hline GAPDH & CGGATTTGGTCGTATTGG & TCAAAGGTGGAGGAGTGG & [12] \\
\hline
\end{tabular}

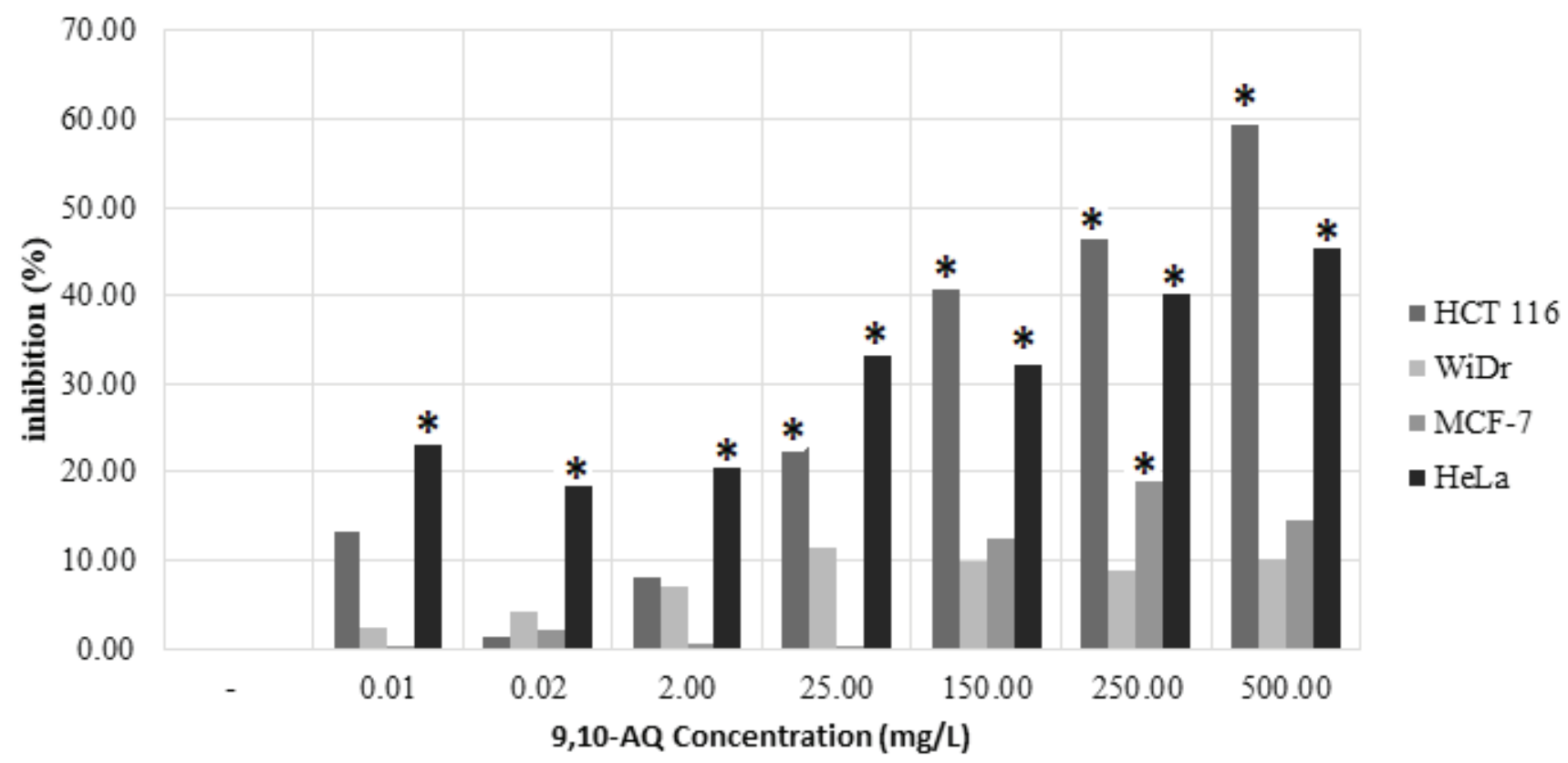

Figure 1. The average inhibition (\%) of cancer cell line growth of HCT 116, WiDr, MCF-7, and HeLa by the 9,10-AQ at the concentrations of 0.01 to $500 \mathrm{mg} / \mathrm{L}$. ${ }^{*}$ : significantly different from the control cell $(P<0.05)$

Lower concentrations ( $<25 \mathrm{mg} / \mathrm{L}$ ) inhibit less than $30 \%$ of the cancer cell line growth. The percentage inhibition displays an increasing trend on HCT 116 cells, and HeLa cells align with the increasing concentrations. The 9,10$\mathrm{AQ}$ does not seem to affect MCF-7 cells and the WiDr cells; it inhibits below $20 \%$ in all concentrations used in this study. The inhibition of 9,10-AQ on HeLa cells growth is about $50 \%$ at a concentration of 250 and $500 \mathrm{mg} / \mathrm{L}$; therefore, the HeLa cells were selected to be further used as a molecular assay model.

Based on cell proliferation inhibition upon 9,10-AQ concentrations, the concentration that can inhibit 50\% cell growth (IC50 value) is determined (Table 2 ). The corresponding IC50 values on WiDr, MCF-7, and HeLa cells are above $500 \mathrm{mg} / \mathrm{L}$, and the IC50 value on HCT 116 is approximately $320 \mathrm{mg} / \mathrm{L}$.
Table 2. Inhibition concentration of $50 \%$ cancer cell growth (IC50) of anthraquinone

\begin{tabular}{lll}
\hline Cancer cells & $\mathrm{IC}_{50}(\mathrm{mg} \mathrm{m} \mathrm{L-1})$ & $\mathrm{IC}_{50}(\mathrm{mM})$ \\
\hline HCT 116 & 321.8 & 1.55 \\
WiDr & $>500$ & $>2.40$ \\
MCF-7 & $>500$ & $>2.40$ \\
HeLa & $>500$ & $>2.40$
\end{tabular}


This study also provides additional physical information. Specifically, upon treatment with 9,10-AQ, cell mortality starts at $500 \mathrm{mg} / \mathrm{L}$ and confirms abnormality in cell morphology (Figure 2). They showed differences in morphology (demonstrated with the arrow on each figure) resulting in the loss of cell-cell contact (A1), plasma membrane destruction (A2), cell disruption (C1), the formation of apoptotic bodies (D1), and cell shrinkage (D2), depending on treatment concentration. The cell control has typical morphological specifications until the completion of the incubation of treatment. On the contrary, with a $500 \mathrm{mg} / \mathrm{L}$ concentration of 9,10$\mathrm{AQ}$, at $0.01 \mathrm{mg} / \mathrm{L}$, the cell growth is not significantly different from the control cells, meaning that the cells still grow well but do not show any proliferation.

To explore the 9,10-AQ's possible mechanisms as an antitumor, we experimented on the level expression of $B A X, B C L 2, P C N A$, and P53 on HeLa cells at a 9,10$A Q$ concentration of 250 and $500 \mathrm{mg} / \mathrm{L}$. The result showed that the $B A X$ and $B C L 2$ level expression increases in the presence of 9,10-AQ 250 and $500 \mathrm{mg} / \mathrm{L}$, but the increase of $B A X$ expression is higher than the increase of $B C L 2$ level expression (Figure 3). The $B A X$ level expression increases about 3.6 and 5 times higher than the control for 9,10-AQ at a 250 and $500 \mathrm{mg} / \mathrm{L}$ concentration. Contrary to the increase of the $B A X$ level expression, $B C L 2$ level expression only increased by approximately 40 and $20 \%$ (compared to control, respectively) for 9,10-AQ at a concentration of 250 and $500 \mathrm{mg} / \mathrm{L}$. The level expression of $P 53$ is increased by about $30 \%$ compared to the control at a concentration of 9,10-AQ of $500 \mathrm{mg} / \mathrm{L}$. In comparison, the expression of PCNA increases by only about $60 \%$ and $40 \%$ compared with control at 9,10-AQ concentration of 250 and 500 $\mathrm{mg} / \mathrm{L}$, respectively.

\section{DISCUSSION}

The 9,10-AQ had been classified as Carc 1B that was sufficient evidence for animal carcinogenicity [3]. The research reported that 9,10-AQ induced tumors in rats, especially in the liver, kidney, urinary bladder, and that 9,10-AQ was carcinogenic only to the liver [13]. In another report, noticeable effects were reported when the rats were administered with 9,10-AQ about $7,500 \mathrm{mg} / \mathrm{L}$, equivalent to $555 \mathrm{mg} 9,10-\mathrm{AQ} / \mathrm{kg}$ body weight [14]. This concentration is indeed an irrational dose (i.e., $555 \mathrm{mg} 9,10-\mathrm{AQ} / \mathrm{kg}$ body weight of rats is equal to $89.95 \mathrm{mg} 9,10-\mathrm{AQ} / \mathrm{kg}$ human body weight), as reported by Shin et al. [15]. it is widely known that vitamins and minerals that are good for health can be toxic if consumed at an excessive or irrational dose [16].

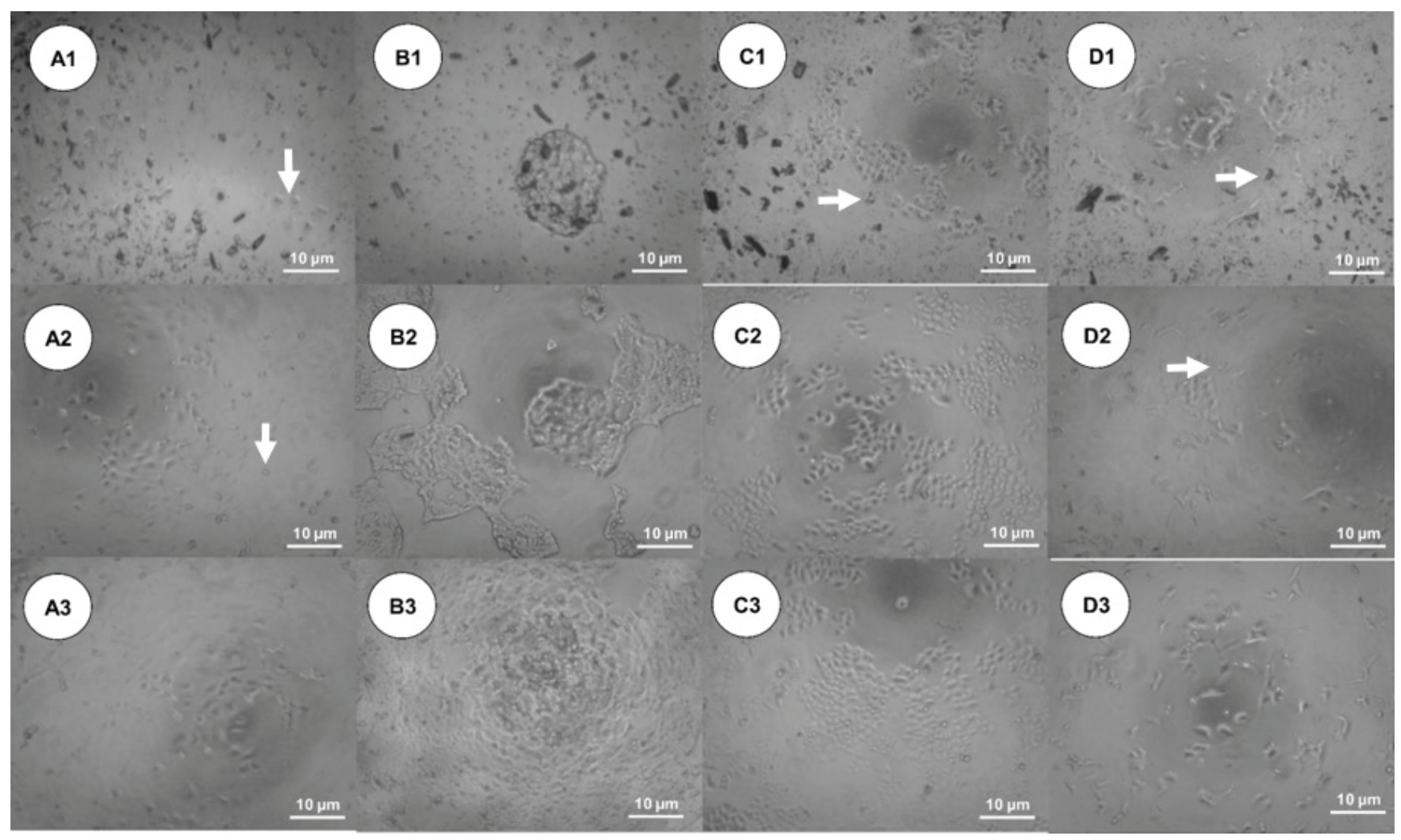

Figure 2. Various concentrations of 9,10-AQ induced morphological effects. $A=H C T 116, B=W i D r, C=M C F-7, D=H e L a, 1=500 \mathrm{mg} / \mathrm{L}$, $2=0.01 \mathrm{mg} / \mathrm{L}$, and $3=$ control cells 


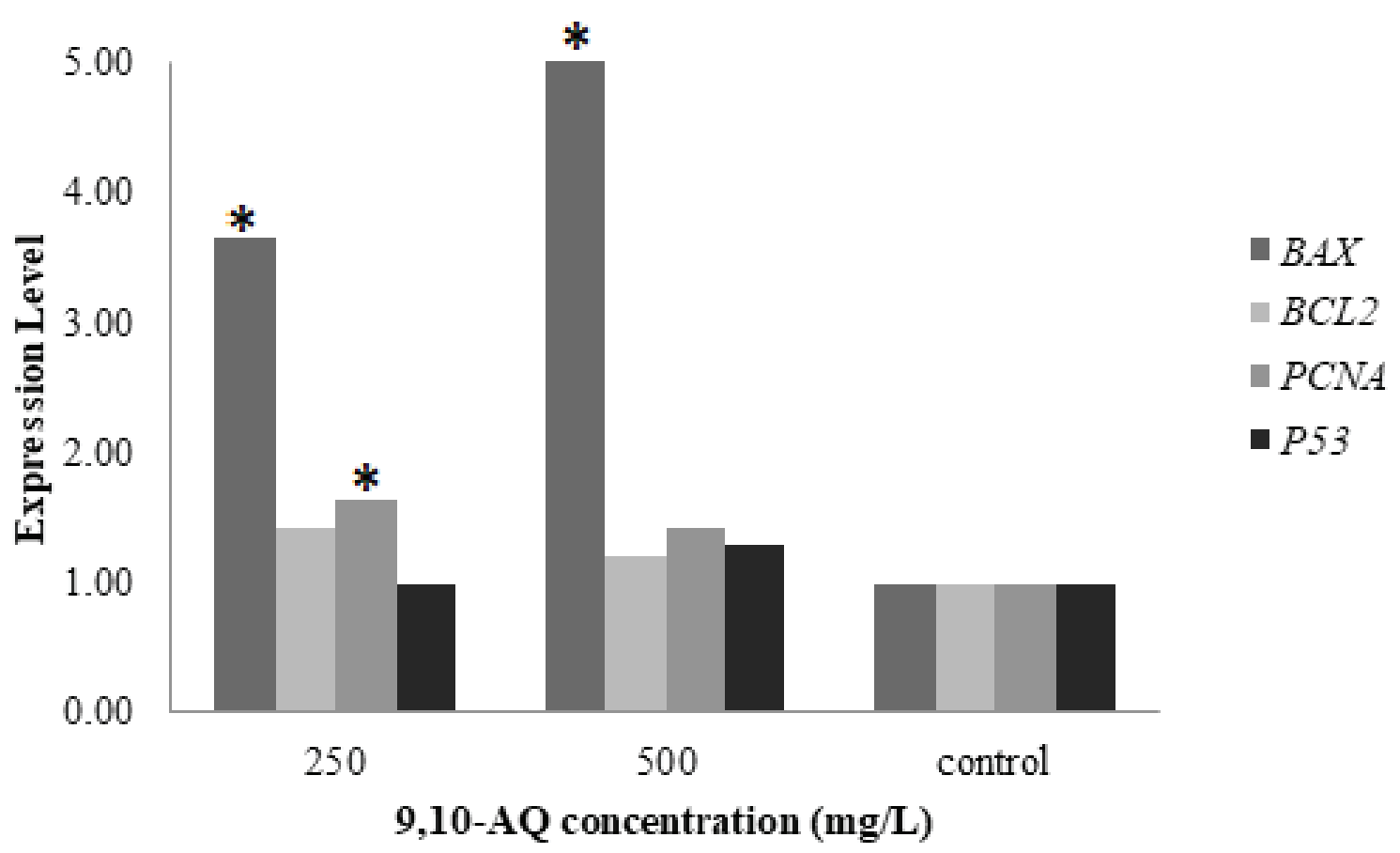

Figure 3. The level expression of $B A X, B C L 2, P 53$, and $P C N A$ on HeLa cells induced by $9,10-A Q$ at 250 and $500 \mathrm{mg} / \mathrm{L}$ concentrations. *: significantly different from the control cell $(P<0.05)$

Our experiment confirms that 9,10-AQ at all tested concentrations do not proliferate the targeted cancer cells, i.e., human intestinal cancer cells, human breast cancer cells, and cervical cancer cells. On the contrary, cancer cell growth was adversely inhibited (Figure 1). The inhibition is increasing as the 9,10-AQ concentration increases. The cell morphology indicates cell mortality when the highest 9,10-AQ concentration $(500 \mathrm{mg} / \mathrm{L})$ was applied (Figure 2). This study follows the hypothesis that different concentrations of 9,10-AQ will affect cancer cell growth. Surprising results show that 9,10-AQ is a potent proliferation inhibition agent, especially against HCT 116 with the IC50 of $1.55 \mathrm{mM}$. Our findings also support minor disturbance on chronic neurotoxic symptoms due to $9,10-A Q$ in humans $[5,6]$. It is also reported that 9,10-AQ can be a potent aggregation inhibitor for Alzheimer's disease [17]. Rhein, an AQ natural product, is also reported as a potential antitumor toward the HeLa cancer cell with IC50 of 1.3-40.0 $\mu \mathrm{M}$ [9]. Other $A Q$ derivatives are also reported as potential anticancer against several cancer lines [8].

Since the 9,10-AQ demonstrates antiproliferation activity against the HeLa cancer cell, the mechanism of action as antiproliferation was further investigated at a molecular level by determining the $B C L-2, B A X, P C N A$, and $P 53$ gene expression. $B C L-2$ (B-cell lymphoma 2 ) is a transmembrane protein that regulates apoptosis (cell death). $B C L-2$ promotes cellular survival and inhibits proapoptotic proteins, including $B A X, B A K, B A D$, and
BIM [10-12,18]. In the presence of $B C L-2$ as an antiapoptotic, BAX's activation will decrease, and the death signal disappears. This study exhibits that 9,10-AQ significantly up-regulates $B A X$ expression (by approximately 3-5 folds) but does not change the expression of $B C L-2$, which implies a sudden rise of $B A X / B C L-2$ ratio in 9,10-AQ treated HeLa cervical cancer cell line about 2,6 and 4.3 folds compared with control cells. It means 9,10-AQ plays a role in the apoptosis of HeLa cell lines.

Proliferating cell nuclear antigen (PCNA) is an acidic nuclear protein related to DNA replication on the transition from the $\mathrm{G} 1$ phase to the $\mathrm{S}$ phase and connected with tumor cells' proliferation [19]. PCNA is an indicator to evaluate the state of cell proliferation [20]. When the expression of PCNA increases, it means cell proliferation increases as well. Our findings show that the increase in PCNA expression is not significant compared to those of control, which means that the 9,10-AQ does not substantially proliferate HeLa cancer cells.

The $P 53$ gene is a tumor suppressor that increases during DNA impairment [21,22]. This gene also contributes to the $\mathrm{G} 1$ phase regulation of the cell cycle. Our results show that the expression of $P 53$ does not increase significantly, only about $30 \%$, even after the administration of $500 \mathrm{mg} / \mathrm{L}$ of 9,10-AQ (Figure 3). Thus, there is no confirming evidence that below the safe dose, the 9,10-AQ does not harm the DNA. 


\section{CONCLUSIONS}

The effect of 9,10-AQ's direct interaction on four different cancer cells, namely human colorectal carcinoma HCT 116, human colon adenocarcinoma WiDr, human breast cancer MCF-7, and human cervical cancer HeLa, demonstrates to inhibit the four cancer cells growth. The 9,10-AQ acted as an inhibition agent against the HeLa cancer cell line by increasing the $B A X$ ratio to $B C L-2$ expression via the apoptosis mechanism. We, therefore, suggest that 0.01 and $0.02 \mathrm{mg} / \mathrm{kg}$ of $9,10-\mathrm{AQ}$ as MRL in agricultural product commodities, including tea, be reconsidered.

\section{DECLARATIONS}

\section{Competing of Interest}

The author(s) declare no competing interest in this study.

\section{Acknowledgement}

This study is an on-going project funded by the Indonesia Endowment Fund for Education (LPDP) in 2018-2019 (Contract Number PRJ-35/LPDP/2018). Appreciation goes to the Indonesia Tea Board for meaningful collaboration in implementing the study.

\section{REFERENCES}

1. DeLiberto ST, Werner SJ. Review of anthraquinone applications for pest management and agricultural crop protection. Pest Manag Sci. 2016;72(10):1813-25.

2. Food E, Authority S. Reasoned opinion on the review of the existing maximum residue levels (MRLs) for anthraquinone according to Article 12 of Regulation (EC) No 396/2005. EFSA J. 2012;10(6):6-11.

3. EFSA. Scientific opinion on pyrrolizidine alkaloids in food and feed: EFSA Panel on Contaminants in the Food Chain (CONTAM). EFSA J [Internet]. 2011;9(11):1-134. Available from: c:\%5CUsers\%5CJ ames\%5CDocuments\%5CDropbox\%5CLiteraturaPDF\%5CBiblio PAs\%5CEFSA2011.pdf

4. European Chemicals Agency. Guidance on the Application of the CLP Criteria [Internet]. European Chemicals Agency; 2017. 1-647 p. Available from: h t t p s : / / e c h a . e u r o p a . e u / documents/10162/23036412/clp_en.pdf

5. O'Donoghue JL. Neurotoxicity of industrial and commercial chemicals. Vol.1. 1st ed. Boca Raton: CRC; 1985.
6. Merck. The Merck Index: An Encyclopedia of Chemicals, Drugs, and Biologicals. 13th ed. O'Neil MJ, Smith A, Heckelman PE BS, editor. Whitehouse Station, NJ, USA; 2001.

7. Sylvester PW. Optimization of the tetrazolium dye (MTT) colorimetric assay for cellular growth and viability. Methods Mol Biol. 2011;716(July):157-68.

8. Schmittgen TD, Livak KJ. Analyzing real-time PCR data by the comparative CT method. Nat Protoc. 2008;3(6):1101-8.

9. Hussain $\mathrm{H}, \mathrm{Al}$-Harrasi A, Al-Rawahi A, et al. A fruitful decade from 2005 to 2014 for anthraquinone patents. Expert Opin Ther Pat. 2015;25(9):1053-64.

10. Crowley LC, Marfell BJ, Scott AP, et al. Dead cert: Measuring cell death. Cold Spring Harb Protoc. 2016;2016(12):1064-72.

11. Flanagan $L$, Lindner $A U$, de Chaumont $C$, et al. BCL2 protein signalling determines acute responses to neoadjuvant chemoradiotherapy in rectal cancer. J Mol Med. 2015;93(3):315-26.

12. Nolte E, Sobel A, Wach $S$, et al. The new semisynthetic cardenolide analog 3ß-[2-(1Amantadine)-1-on-ethylamine]-digitoxigenin (AMANTADIG) efficiently suppresses cell growth in human leukemia and urological tumor cell lines. Anticancer Res. 2015;35(10):5271-6.

13. Doi AM, Irwin RD, Bucher JR. Influence of functional group substitutions on the carcinogenicity of anthraquinone in rats and mice: Analysis of longterm bioassays by the National Cancer Institute and the National Toxicology Program. J Toxicol Environ Heal - Part B Crit Rev. 2005;8(2):109-26.

14. Public Health Service. NTP Technical Report on the Toxicology and Carcinogenesis Studies of Primidone (Feed Studies) National Toxicology Program [Internet]. Vol. NTP TR 494. North Columbia; 2005. Available from: http://eds.a.ebscohost.com.ezproxy. endeavour.edu . a u / eds / pdfviewer/ pdfviewer?sid=1e83dda5-700a-4db9-9540f3b04ec02cd6@sessionmgr4004\&vid=8\&hid=4205

15. Shin J, Seol I, Son C. Interpretation of Animal Dose and Human Equivalent Dose for Drug Development. J Korean Orient Med. 2010;31(3):1-7.

16. Wooltorton E. Too much of a good thing? Toxic effects of vitamin and mineral supplements. Cmaj. 2003;169(1):47-8.

17. Convertino $M$, Pellarin $R$, Catto $M$, et al. 9,10-Anthraquinone hinders $\beta$-aggregation: How does a small molecule interfere with $A \beta$-peptide amyloid fibrillation? Protein Sci. 2009;18(4):792-800.

18. Wahyuningsih MSH, Mubarika S, Ganjar IG, et al. $5 \alpha$-Oleandrin reduce $\mathrm{Bcl}-2$ protein and increase Bax protein expression on Hela cervical cancer cell. Universa Med. 2017;36(2):102. 
19. Long L, Li Q. The effect of alkaloid from Oxytropis ochrocephala on growth inhibition and expression of PCNA and p53 in mice bearing $\mathrm{H} 22$ hepatocellular carcinoma. Yakugaku Zasshi. 2005;125(8):665-70.

20. Lu Z, Xiao $Y$, Liu $X$, et al. Matrine reduces the proliferation of A549 cells via the p53/p21/PCNA/ elF4E signaling pathway. Mol Med Rep. 2017;15(5):2415-22.
21. Farnebo M, Bykov VJN, Wiman KG. The p53 tumor suppressor: A master regulator of diverse cellular processes and therapeutic target in cancer. Biochem Biophys Res Commun. 2010;396(1):85-9.

22. Pflaum J, Schlosser S, Müller M. P53 family and cellular stress responses in cancer. Front Oncol. 2014;4(OCT):1-15. 